\title{
Formation of the National Guard Officers' Information and Communication Competence in the Russian Federation
}

\author{
R. Streltsov \\ Department Designs Armored Techniques, Perm Military \\ Institute of the Russian troops of the National Guard, \\ Perm, Russia \\ romn.streltsov@gmail.com, Streltsov86@rambler.ru
}

\section{A. Burgonutdinov}

Department of Highways and Bridges, Perm National Research Polytechnic University, Perm, Russia

burgonutdinov.albert@yandex.ru

\author{
T. Lavina \\ Department of Information Technology, I.Yakovlev \\ Chuvash State Pedagogical University, K. Marksa St., 38, \\ Cheboksary, Russia \\ tlavina@mail.ru
}

\section{Zolnikov}

Technical Training Department, Perm Military Institute of the Russian troops of the National Guard, Perm, Russia zvigor@mail.ru

\begin{abstract}
The purpose of the study is to examine the methodological approaches to the organization of information and communication training of the military. The paper describes the essence of the informational component of cultural, vocational and professional competences that are formed by the graduates of military schools (on the basis of National Guard troops of the Russian Federation). The study shows the importance of the use of information and communication technologies in the armed forces of different countries, as well as the formation of information and communication competence among military personnel. The article gives the concept of information and communication competence of the officers of the troops of the national guard of the Russian Federation. The criteria for assessing the formation of information and communication competence of officers (motivational, cognitive, activity-oriented) are singled out. The levels of the formation of information and communication competence were checked, and the results of experimental work on the formation of this competence among the military personnel are presented. Thus, the matrix of interaction between the competences of military personnel of different profiles is built. The formation of militaryprofessional competences is provided by obtaining a complex of knowledge and skills of management units in modern combined armed combats and armed conflicts.
\end{abstract}

Keywords-professional military competences; training of officers; information technologies; military activity; criteria for evaluation; military personnel.

\section{INTRODUCTION}

The authors' study on the formation of information and communication competence of officers was stimulated by the importance of the problem posed by the educational paradigm of military specialists of the 21 st century.

The main objective is the analysis of the competences formed by the officers of National Guard troops of Russia, the isolation of the informational component of these competencies, and the development of the interoperability matrix to find the optimal ways for the educational process aimed at the formation of information and communication competence (ICT).

In the world modern armies great attention is paid to the information component and a lot of money is spent on it $[1,2]$. For example, in the United States of America the center for information strategy and policy was created, with the aim of using information technologies in military conflicts of the $21 \mathrm{st}$ century, in all the divisions (Air force, Navy, etc.) there were also created positions for officers who deal with information warfare techniques. It is emphasized that the focus of the armed struggle in the 21 st century will be information warfare, and domination in information technology will be the main victory condition. In this regard, special attention is paid to training specialists in ICT [3].

The problem of the use of information and communication technologies has been widely discussed by researches [4-6]. Directions for the use of ICT in education and the general principles of automated training system are explored by Robert [7]. Moon and Im [8] consider the possibility of the application of ICT for the prevention of road accidents, as well as other accidents, in the Korean army. The work of $\mathrm{Su}, \mathrm{Wu}$, Zheng, Zhang, and Jiang [9] examines the integration of information technology into the structure of the army to effectively address the tactical task forces. De Corte, Linn. Mandl, and Verschaffel [10] describe the latest research and modern methodological approaches to the use of ICT to promote knowledge. The procedure for the use of computer learning, virtual reality and other new technologies are explored by Seidel and Chatelier [11].

Friedl and O'Niel [12] study the possibility of using 
computer games and simulation for various situations in military medical training done in the United States. Pullen, Hieb, Levine, Tolk, and Blais [13] analyze the principles of the joint command of NATO coalition forces, with the usage of the ICT tools in the context of warfare. Pullen and Khimeche [14] discuss the current state of information systems and technologies used for military purposes. Kok [15] studies training specialists in the field of improving the process of strategic decision making performed by air command and NATO staff. This system helps timely effective planning and monitoring air operations.

Study of the potential of virtual reality for the US arms industry is done in the work of Lele [16]. Proaps and Bliss [17] study the development of specific skills of military personnel in the use of video games. The use of innovative technologies as an integral part of training soldiers is explored by Alexander, Westhoven and Conradi [18].

\section{MATERIALS AND METHODS}

Analysis of scientific literature allows concluding that, despite significant steps made in the use of information and communication technologies in the National Guard forces of the Russian Federation, there are still some pressing issues related to the training of officers in this area.

The research was done on the basis of the Perm military Institute of National Guard troops of the Russian Federation.

The following profiles of training were analyzed:

- "Use and operation of automated systems for special purposes".

- Specialization in "Operation of computing machines, complexes, systems and networks".

- "Mathematical software and information support of computing machinery and automated systems".

- "Special purpose vehicles".

- "Military tracked and wheeled machines".

- "Small arms and cannon, artillery and rocket weapons".

- "Maintenance of armament and military equipment (fields and types)".

- "Dog handling".

- "Logistical support".

Furthermore, a matrix of interactions between their competences and the information component of different profiles of training of officers is presented.

\section{RESULTS AND DISCUSSIONS}

The introduction of modern information and communication technologies in military service and daily activities of the troops is going on very fast. The range of knowledge, abilities and skills received by graduates of military schools, unfortunately, does not meet modern requirements. Therefore, the development of information and communication technologies should be accompanied by continuous training of officers in this area.
Officers' skills in information and communication technologies should be formed at a higher educational institution being based on those competences, which are determined by the Federal State standard of the third generation.

The wide range of applications of information and communication technologies define the objects of the officer's professional activity, such as:

- the military service and combat activities of operational and territorial associations, formations, military units and institutions;

- organization of management automation;

- objects of information and telecommunication system, local area network;

- organization and comprehensive resourcing of military service;

- military training, education, military discipline and morale of personnel;

- use, operation and safety of technical means, property and other material resources.

In this regard, the task, facing higher military education, to prepare information-communication competent military personnel is of great importance, because such competence enables one to convert their knowledge and skills into solutions of specific problems. It enhances the officer's ability to take decisions, to effectively use their potential and to develop their skills through obtaining new information and its integration into the area of the officer's professional activities and official duties [19].

Thus, the information-communication competence of an officer will be understood as their professional and personal training which embraces the need to get theoretical knowledge and practical skills, continuous education and self education in the ICT sphere, motivation for studying the potential of ICT application, awareness of the ways of ICT employing in accordance with the objects of the officer's professional activity (routine and combat activities, management automating including local area networks, combat training, and personnel development ).

Accordingly, the following evaluation criteria will be adopted to assess the officer's information-communication competence: a motivational criterion (need to acquire knowledge and skills, continuous education and self education in the ICT sphere, motivation for studying the potential of ICT application); a cognitive criterion (awareness of the ways of ICT employment for solving professional problems); and an action-related criterion (skills of using ICT in solving professional problems and management automating).

Analyzing the common cultural, professional, vocational, military and professional competences formed by the graduates of military schools, irrespective of the training profile, one can conclude that more attention is paid to information technology.

Along with the common competences, a graduate of a 
military school must have military-professional competences, the specifics of which reflect the actual activity of the officer of the troops of the National Guard of Russia.

The formation of the professional competences of any graduate is provided through obtaining a complex of knowledge, abilities and skills of managing units in the modern combined armed combat, armed conflict, state of emergency, when conducting counter-terrorism operations, as well as in peacetime.

Today high quality executions of these tasks are unimaginable without commanders' mastering modern information and communication technologies.

Information and communication competence is as one of the main skills. Also it is a part of other competences, such as the military-professional competence and vocational competence.

The development of information and communication competence means:

- psychological readiness to use information and communication technologies (particularly by senior officers);

- obtaining key knowledge in the field of information and communication technologies, allowing responding quickly to the changing environment, as far as the accomplishment of tasks is concerned;

- awareness of the importance of mastering information and communication technologies in the modern society, particularly in the army;

- the perception of Information and communication competence by military personnel as a new fundamental paradigm, allowing one to acquire new knowledge with the aim of obtaining a new result;

- the skill of selecting and using software for the optimization of professional activity;

- the continuity of military personnel training in the field of information and communication technologies.

Today there are many ways to develop officers' information and communication competence [20]. The improvement of the informatization process and its development is facilitated by many factors, such as provision of higher military schools and the troops with modern information and communication technologies, formation of a single information resource, targeted continuous training of military personnel in the field of information and communication technologies [21].

So, what is the place of the information and communication competence in the officer's professional development? The competence of a soldier is determined by his professional training, except basic directions, such as, firearms training, physical training, tactical training etc. (However, all this does not exclude, but rather involve the use of information and communication technologies).
TABLE 1. INFORMATION AND COMMUNICATION COMPETENCE

\begin{tabular}{|c|c|c|}
\hline \multicolumn{2}{|c|}{ Competences } & Information and communication competence \\
\hline \multirow{2}{*}{ Cultural } & $\mathrm{C}-4$ & generalization, analysis, classification, prediction \\
\hline & C-6 & $\begin{array}{l}\text { creating and editing texts for professional } \\
\text { purposes }\end{array}$ \\
\hline \multirow{5}{*}{$\begin{array}{c}\text { General } \\
\text { professional }\end{array}$} & GP-3 & development of innovative projects \\
\hline & GP-4 & ability to use languages and system programming \\
\hline & GP-6 & $\begin{array}{l}\text { ability to include modern trends in computer, } \\
\text { information and telecommunication technologies } \\
\text { into professional activities }\end{array}$ \\
\hline & GP-7 & $\begin{array}{l}\text { understanding the nature and significance of } \\
\text { information in the development of the modern } \\
\text { information society, } \\
\text { compliance with the basic requirements of } \\
\text { information security }\end{array}$ \\
\hline & GP-8 & $\begin{array}{l}\text { command of the basic methods, ways and means } \\
\text { of obtaining, storing, processing information, } \\
\text { skills of work with computer as an information } \\
\text { management tool }\end{array}$ \\
\hline \multirow{8}{*}{ Professional } & Pr-1 & $\begin{array}{l}\text { ability to apply achievements of modern } \\
\text { information technology for retrieving and } \\
\text { processing information according to the profile } \\
\text { of activity in computer networks }\end{array}$ \\
\hline & Pr-2 & $\begin{array}{l}\text { ability to develop and debug software used to } \\
\text { calculate military units provision with weapons } \\
\text { and ammunition }\end{array}$ \\
\hline & Pr-6 & $\begin{array}{l}\text { ability to use the application software to calculate } \\
\text { components, assemblies and systems for special } \\
\text { vehicles }\end{array}$ \\
\hline & Pr-7 & $\begin{array}{l}\text { ability to use information technology for } \\
\text { developing design and technical documentation } \\
\text { for the production of new or modernized samples } \\
\text { of vehicles }\end{array}$ \\
\hline & Pr-8 & $\begin{array}{l}\text { ability to use information technology, electronic } \\
\text { computing equipment when performing service } \\
\text { and combat missions }\end{array}$ \\
\hline & $\operatorname{Pr}-14$ & $\begin{array}{l}\text { ability to control the quality of hardware, } \\
\text { software and information support }\end{array}$ \\
\hline & $\operatorname{Pr}-15$ & $\begin{array}{l}\text { ability to organize technical control in the } \\
\text { research, design, manufacture and operation of } \\
\text { special purpose vehicles }\end{array}$ \\
\hline & Pr-16 & $\begin{array}{l}\text { ability to make plans, programs, schedules, } \\
\text { estimates, orders, requests, instructions and other } \\
\text { technical documentation }\end{array}$ \\
\hline \multirow{4}{*}{$\begin{array}{l}\text { Military- } \\
\text { professional }\end{array}$} & MP-16 & $\begin{array}{l}\text { ability to organize the implementation of the } \\
\text { information resources and services }\end{array}$ \\
\hline & MP-24 & $\begin{array}{l}\text { ability to carry out informational and educational } \\
\text { work }\end{array}$ \\
\hline & MP-30 & $\begin{array}{l}\text { ability to protect personnel from information and } \\
\text { psychological influence of the enemy }\end{array}$ \\
\hline & MP-37 & ability to organize inventive and innovative work \\
\hline \multirow{2}{*}{ Vocational } & $\mathrm{V}-1.2$ & $\begin{array}{l}\text { ability to perform professional activities at all } \\
\text { stages of producing military tracked and wheeled } \\
\text { vehicles using advanced technologies and } \\
\text { methods of production }\end{array}$ \\
\hline & $\mathrm{V}-1.3$ & $\begin{array}{l}\text { ability to exploit computing facilities of special } \\
\text { purpose automated systems }\end{array}$ \\
\hline
\end{tabular}

Higher educational institutions prepare for employment in military forces such specialists as engineers, educators, dog handlers, experts in chemistry and automated management 
tools, commissaries and many others. So, what is the role of information and communication competence in the formation of the modern military professional?

To answer this question, the authors constructed a matrix of interaction between military competences, aiming at separating the information and communication component from general cultural, professional, military professional, professional and specialized competences.

Table 1 shows that the role of the information component in all the officers' competences is fundamental. Hence, the formation of military personnel's skills and abilities in their preparation for professional activity should be based on the interplay of the various disciplines for a more profound study of the potential of information and communication technologies.

To check the level of the formation of information and communication competence, the authors used questionnaires (assessing motivational component) and tests (assessing cognitive component). Graduates performed a complex project in which they were supposed to use ICT to solve a certain quasi-professional problem. The level of the formation was defined on the basis of peer review done by the lecturers of a military higher educational institution. The research employs the following quantitative indicators: 1 point - low level; 2 points - medium level; 3 points - high level.

The total score varies from 19 to 57 points for all the indicators of the competence component formation. The choice of intervals in defining the level borders was made for all the indicators on the basis of the methods developed by V.P. Bespalko.

The quantitative assessment of the formation level borders for all the components is shown in Table 2.

TABLE 2. BORDERS OF LEVELS OF THE INFORMATION-COMMUNICATION COMPETENCE FORMATION.

\begin{tabular}{|c|c|c|c|}
\hline Level & Low & Medium & High \\
\hline Points & $19-29$ & $30-40$ & $41-57$ \\
\hline
\end{tabular}

The ratio of the combined characteristics of the motivational, cognitive and action-related components was calculated according to formula: $\frac{\Sigma_{\mathrm{i}}^{n}=n K_{\mathrm{i}}}{n * 192} * 100 \%$, where $\mathrm{K}-$ the number of answers to each question, $\mathrm{i}$ - the number of the question, $\mathrm{n}$ - the number of questions, 192 - the total number of respondents. Table 3 illustrates the combined average absolute and relative indicators of the formation of the motivational, cognitive and action-related components according to the levels.

TABLE 3. INDICATORS OF FORMATION OF MOTIVATIONAL, COGNITIVE AND ACTION-RELATED COMPONENTS OF THE INFORMATION AND COMMUNICATION COMPETENCE.

\begin{tabular}{|c|c|c|c|c|c|c|}
\hline Components & \multicolumn{2}{|c|}{ Low } & \multicolumn{2}{c|}{ Medium } & \multicolumn{2}{c|}{ High } \\
\hline & absolute & relative & absolute & relative & absolute & relative \\
\hline Motivational & 18 & $9.4 \%$ & 30 & $15.6 \%$ & 144 & $75.0 \%$ \\
\hline Cognitive & 8 & $4.2 \%$ & 39 & $20.3 \%$ & 145 & $75.5 \%$ \\
\hline $\begin{array}{c}\text { Action- } \\
\text { related }\end{array}$ & 0 & $0.0 \%$ & 25 & $13.0 \%$ & 167 & $87.0 \%$ \\
\hline
\end{tabular}

The results show that the majority of military schools graduates (over 75\%) show the high level of the formation of the information and communication competence.

\section{CONCLUSION}

Thus, having analysed the information and communication component of officers' competences, the authors conclude that today this component plays a decisive role in training modern army officers. The information and communication competence is an essential component of competences of other kinds. Inconsistency of officers training in the field of information means and communication technologies is revealed, it does not correspond to the requirements for future practical activities of military specialists.

The results of this study can enhance the organization of training of officers in the field of information means and communication technologies regardless of a preparation profile; the competence interaction matrix allows for the better use of the information component in the training of military personnel.

\section{References}

[1] Ellis, B., and A. H. Normore, "Effective Engagement and Communication between First-Line Police Supervisors and Police Officers," Handbook of Research on Effective Communication, Leadership, and Conflict Resolution, 479-93, 1992.

[2] I. N. Klepatskya, "The Implementation of Innovative Pedagogical Technologies in the Teaching of Reading in a Foreign Language of Cadets of a Military Higher Educational Establishment," 5th International Scientific-Practical conference "Pedagogical Skills and Pedagogical Technologies," Cheboksary: CNS "Interaktiv plus," pp, 8385, 2015.

[3] I. Panarin, Media, Propaganda and Information War. Moscow: Generation, 2012.

[4] A. Laajalahti, J. Hyvärinen, and M. Vos, "Crisis Communication Competence in Co-Producing Safety with Citizen Groups." The Social Sciences, vol. 5 (1), p. 13, 2016.

[5] S. D. Lane, Interpersonal Communication: Competence and Contexts. 2 edition. Routledge, 2016.

[6] H. Taboli, M. Ravari, M. Kamali, N. Alipour, and V. Bakhtiyari, "Role of Management Information Systems in Virtual Organizations," The Social Sciences, vol, 11,pp. 6386-6390, 2016.

[7] I. V. Robert, "The Interpretation of the Words and Phrases of the Conceptual Apparatus of Informatization of Education," Computer Science and , vol. 6, pp. 63-70, 2004.

[8] M. Hoseok, and Y. Im, "The Study on a Notification Service for Preventing Accidents Using an Analysis for Stress of Enlisted Men in Korean Army," Journal of the Korea Society of IT Services, vol. 15 (1), pp. $255-268,2016$.

[9] B. Su, H. Wu, X. Zheng, K. Zhang, and Q. Jiang, "Army Tactical Information System Software Framework Based on Soa Design China Intelligent Transportation," Proceedings of International Conference on Intelligent Transportation "Big Data and Smart City," pp. 137-139, 2015.

[10] De C. Erik, M. C. Linn, H. Mandl, and Lieven Verschaffel, eds. Computer-Based Learning Environments and Problem Solving. Berlin, Heidelberg: Springer Berlin Heidelberg, 1992.

[11] R. J. Seidel, and P. R. Chatelier, Virtual Reality, Training's Future? : Perspectives on Virtual Reality and Related Emerging Technologies, Berlin: Springer Science \& Business Media, 2013. 
[12] Friedl, E. Karl, and H. F. O'Neil, "Designing and Using Computer Simulations in Medical Education and Training: An Introduction," Military Medicine, vol. 178 (10S, pp. 1-6, 2013.

[13] M. J Pullen,., M. R. Hieb, S. Levine, A. Tolk, and C. Blais. Joint Battle Management Language - US Contribution to the C-BML PDG and NATO MSG-048 TA, 2014.

[14] M. Pullen, and L. Khimeche. "Advances in Systems Technologies Toward Interoperating Operational Military $\mathrm{C} 2$ and Simulation Systems," 19th International Command and Control Research and Technology Symposium, 2014.

[15] Kok, Ayse. "A Conceptual Design Model for CBT Development: A NATO Case Study." Education and Information Technologies, vol. 19 (1), pp. 193-207, 2014.

[16] L.Ajey, "Virtual Reality and Its Military Utility," Journal of Ambient Intelligence and Humanized Computing, vol. 4 (1), pp. 17-26, 2013.
[17] A. B. Proaps, and J. P. Bliss, "The Effects of Text Presentation Format on Reading Comprehension and Video Game Performance," Computers in Human Behavior, vol. 36, pp. 41-47, 2014.

[18] A.Thomas, M.Westhoven, and J. Conradi, Virtual Environments for Competency-Oriented Education and Training, Advances in Human Factors, Business Management, Training and Education, 2017, 23-29.

[19] M. Brzoska, "Climate Change and the Military in China, Russia, the United Kingdom, and the United States," Bulletin of the Atomic Scientists, vol. 68 (2), pp. 43-54, 2012.

[20] X. Liu, "Institutional Dilemmas and the Development of Chief Information Officer System: A Case from Shanghai," Proceedings of the 17th International Digital Government Research Conference on Digital Government Research, pp. 220-225, 2016.

[21] J. W. Masland, , and L. I. Radway, Soldiers And Scholars Military Education And National Policy, Princeton University Press, 1957. 